\title{
A Burning Experiment Study of an Integral Medical Waste Incinerator
}

\author{
Rong $\mathrm{Xie}^{1}$, Jidong $\mathrm{Lu}^{1}$, Jie $\mathrm{Li}^{1}$, Jiaqiang $\mathrm{Yin}^{2}$ \\ ${ }^{1}$ State Key Laboratory of Coal Combustion, Huazhong University of Science and Technology, Wuhan, China \\ ${ }^{2}$ Huangshi Zhong You Environmental Protection Corporation, Huangshi, China \\ E-mail: xierong0124@foxmail.com \\ Received May 6, 2010; revised June 12, 2010; accepted July 15, 2010
}

\begin{abstract}
Mass burning of the medical waste is becoming attractive in China because Chinese government has banned landfilling of medical waste. Many advantages can be found in this method, such as reduction in waste volume, destruction of pathogens and transformation of waste into the form of ash. However, the medical waste with high moisture in China is not suitable to be treated in the present direct mass burning incinerators. In this paper, a novel integral incinerator is developed with combining a feeder, a rotary grate, a primary combustion chamber (PCC) and a "coaxial" secondary combustion chamber (SCC) into a unique unit. Its capability is 10 ton/day. As the air excess level in the PCC was only $40 \%$ stoichiometric ratio, the PCC acted as a gasifier. The 1.0 excess air ratios in the SCC preserved the purpose of full combustion of flue gas. Temperature and pollutants concentration in the SCC were measured to understand the combustion behavior of volatile organics. Emission concentrations of pollutants before stack were also tested and compared with the China National Incineration Emission Standard.
\end{abstract}

Keywords: Medical Waste, Incineration, Mass Burning, Emission Pollutants

\section{Introduction}

With high-rate economic growth and urbanization in China, the amount of medical waste increased continuously at the rate of $8.98 \%$ since 1980 s [1,2]. The citizens and governor have to face the inevitable challenge of the medical waste treatment. As the hazardous waste landfill standard took effect in 2001, the sanitary landfill of medical waste was banned in China [3]. Not only because the medical waste contained a great quantity of bacteria and viruses and threaten the surroundings of the landfill, but also the available area for landfill has become scarce.

Incineration of medical waste and disposal of the resultant ash by landfill is now accepted as an environmentally friendly disposal method. Its advantages are the destruction of pathogens, reduction in the volume and transform of waste in the form of ash [4].

The mass burning medical waste incinerators includes three basic types: 1) the modular incinerator, 2) the conventional grate-fired incinerator, 3) the rotary kiln incinerator.

Among them, modular medical waste incinerators are the largest number among mass burn installations [5]. The modular incinerator is a compact furnace in the form of a cube with multiple internal baffles. Each modular chamber normally has one or two burners to maintain its required operating temperature. The excess air level is well above stoichiometric, typically $150 \%-200 \%$ excess air. This kind of incinerator is not easily adaptable for continuous operation [6].

The grate-fired medical waste incinerator can be divided into: 1) fixed grate incinerator, 2) moving grate incinerator. Moving grate incinerators are mainly in use today, as medical waste can be stirred and ash removal can be automated. The moving grate incinerator includes one chamber, where medical wastes go through heating, drying, pyrolysis, ignition and burning on the grate. The total injected air is about $120 \%-160 \%$ of the stoichiometric air requirement. However, experiences and trials in South Africa show that the moving gratefired incinerators are unsuitable to treat medical for its high emission loads [7].

The rotary kiln system is widely used to treat hazardous waste. The raw medical waste can be fed directly to the kiln. All reactions such as organic thermal decomposition and char oxidation reactions occur within the rotary reactor. The rotary kiln can produce intensive turbulence and mix air and solid phases completely [8]. But 
the high combustion efficiency is still depended on high auxiliary fuel consumption. Gas sealing of kiln and fixed parts is also a difficult problem.

The three types of incinerators mentioned above presented good performance in the mass burning of solid waste with high heat value (more than $2000 \mathrm{kcal} / \mathrm{kg}$ ). However, in China little experience is available of these incinerators to treat medical waste of high moisture.

In this paper, an integral medical waste incinerator is developed from the following consideration: 1) Achieve flue gas emission limits. 2) Reduce heat loss of the incinerator. 3) Make full use of medical waste's heat value. The integral medical waste incinerator combines a feeder, a rotary grate, a primary chamber and a "coaxial" secondary combustion chamber into a unique unit. The incineration feeding system continuously feeds medical waste into the incinerator. Heating, drying, pyrolysis of medical waste and char oxidation occur in the primary chamber, while gas phase oxidation reactions occur in the secondary chamber. As there is no similar structure of incinerator to our knowledge, the objective of this study are to introduce its novelty, investigate its performance and measure the combustion pollutants.

\section{Incinerator System Description}

The diagrammatic sketch of incineration system and waste treatment process is shown in Figure 1. The basic com- ponents in the incineration system are the waste feed system, the combustion system and the air quality control system. The ash disposal and heat recovery are taken as a supplemental process. The details are described as following.

\subsection{Feeding System}

The special bin storing medical waste is weighed and loaded by the automatic crane, which charges waste into a 2-meter high chute ( $\mathrm{C}$ in Figure 2). Two steel clapboards are installed in the chute to maintain good seal (B and $\mathrm{E}$ in Figure 2). So the chute can not only prevent air flowing into the primary chamber, but also prevent fire from the combustion chamber entering the feeding system. A reciprocating propeller (D in Figure 2) installed in the chute feeds the waste into the primary combustion chamber.

\subsection{Primary Combustion Chamber}

The primary combustion chamber (PCC) consists of a 1.2-meter diameter cylinder and a rotary grate. The grate is installed at the bottom of the PCC. The rotary grate is made up of three discs fixed on the central bearing body and one cone fixed on the top disc. Medical waste, pyrolysates and bottom ashes are tumbled slowly with the rotation of the grate. Many small holes (5-cm diameter)

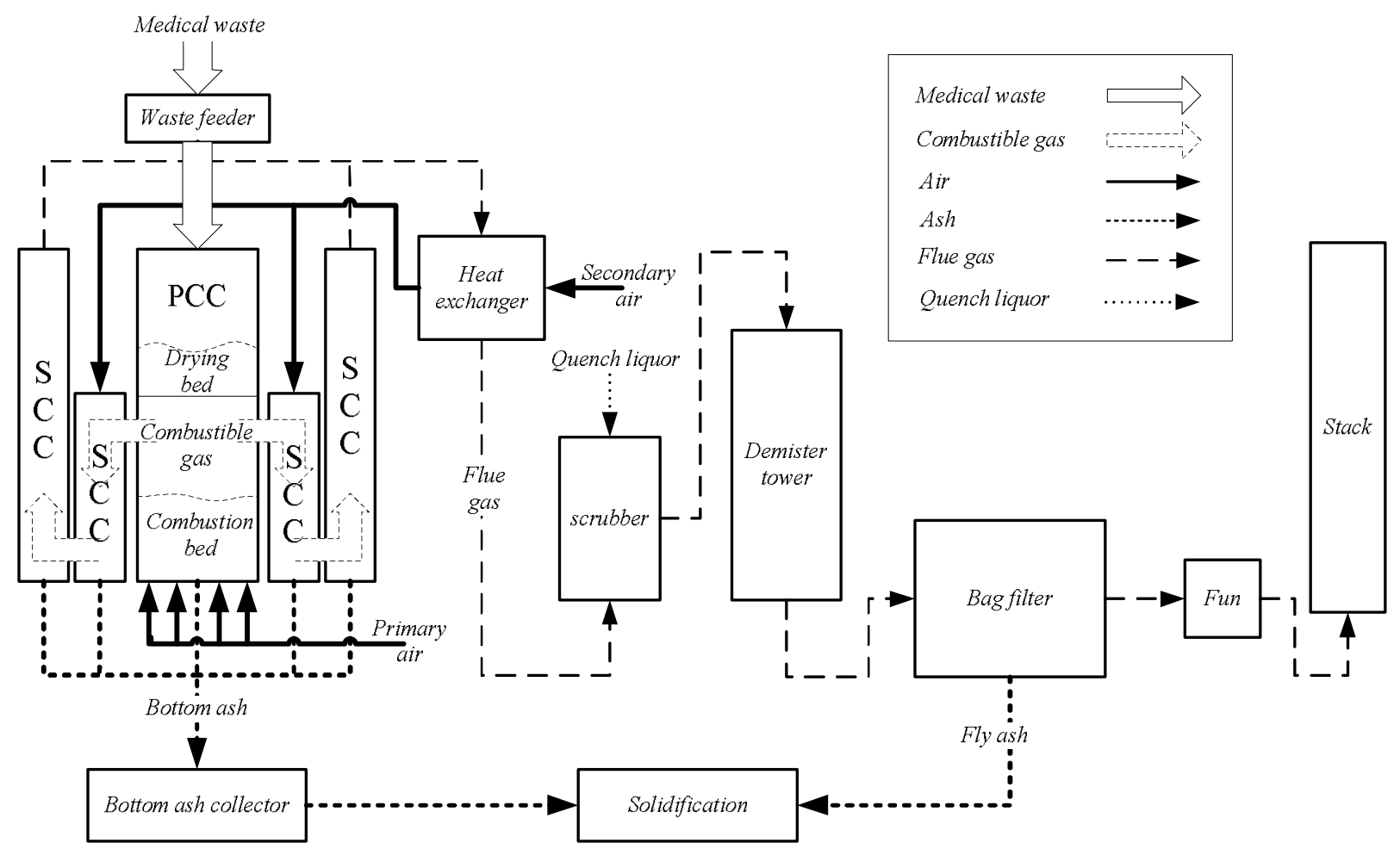

Figure 1. Schematic diagram of incineration system. 


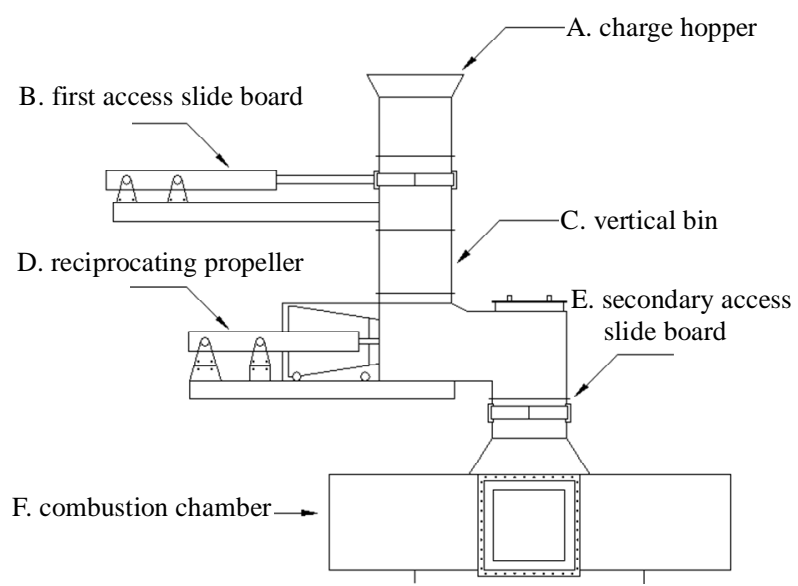

Figure 2. Schematic diagram of the feeding system.

distribute symmetrically on each disc. So the holes with the space between discs can distribute air homogeneously.

In the PCC, The raw medical waste is distributed uniformly onto the waste bed by the feeding system and forms about 1.5 meters waste bed on the surface of the rotary grate. Continuous feeding and slagging make the waste bed maintained at a fixed height. The raw medical waste undergoes heating and drying process on the the waste bed as soon as the raw medical waste enters. This process removes the moisture in the raw medical waste. When the temperature of medical waste rises up to a level, the pyrolysis and volatilization of the solid medical waste start. After pyrolysis and volatilization process, the remained solid char is further oxidized and forms hot slag.

The air for the solid char combustion is drawn from the bottom entrance of the PCC at the room temperature by a forced draft fan. The "cold" air runs through the hot slag layer on the surface of the rotary grate. So the air is heated up while the hot slag is cooled down. The cooled slag forms a protective layer on the surface of the rotary grate, which isolates the grate from the high temperature combustion region. The grate is free from heat transfiguration during the combustion process.

The heated air is then transferred into the combustion area-solid carbon oxidation layer. The char can be oxidized completely under full excess air and produce lots of hot flue gases. These hot flue gases pass through the pyrolysis layer and upwards into the heating and drying layer. The heat in the hot gases can supply enough energy for pyrolysis and drying process of the raw medical waste.

\subsection{Secondary Combustion Chamber}

The secondary combustion chamber (SCC) has a distinct cylinder configuration. We call it "coaxial" structure, as it surrounds the PCC with the same vertical axis. This design significantly decreases the PCC and the SCC outer jacket's contact area with the environment. No pipeline is needed for connection between the PCC and the SCC, so the heat loss in pipeline occurring in traditional multi-chamber incinerator is eliminated. The baffles are installed in the SCC to guide the combustion gases through $180^{\circ}$ turn in vertical directions. This "U" shape combustion channels can significant increase gas turbulence in the high temperature region. In case of the same volume of the combustion chamber, the length of flue gas channel is increased relatively, so the residence time of flue gas at temperatures exceeding $800^{\circ} \mathrm{C}$ is ensured for at least 2 seconds. Secondary air is preheated by a heat exchanger and supplied at the top of the secondary combustion chamber. The secondary air injector is fixed in tangential direction to achieve well mixed effect.

Manipulation of combustion in the SCC includes '3Ts' combustion control (temperature, time and turbulence) in order to maximize system efficiency and minimize environmental adverse effect of the incineration. If the combustion temperature is below $800^{\circ} \mathrm{C}$ the ignition equipment will start automatically and auxiliary fuel is injected to maintain the temperature. In fact the fuel injection is necessary when the mass burning starts. When combustion is stable, the heat release from oxidation reactions can keep temperature exceeding $800^{\circ} \mathrm{C}$.

\subsection{Flue Gas Purification System}

After incineration, the flue gases pass through the pipe and enters the into the flue gas purification system. In order to prevent the erosion by acidic flue gas and flushing by the entrained particles, a thin layer of silicon carbide is coated on the surfaced of the pipe. The flue gas is then induced into semidry scrubbing system. Lime slurry is injected by a spry nozzle in the scrubber. It has high and stable removal efficiency for $\mathrm{HCl}$ and $\mathrm{SO}_{\mathrm{X}}$. No wastewater treatment equipment is required. After that, flue gas goes through the demister tower. Activated carbon is injected into the flue gas to absorb the dioxins and furans formed in the post combustion process before it enters the baghouse. Finally the purified flue gases are induced into the stack by diversion fun.

\section{Medical Waste Incineration Experiments and Results}

\subsection{Waste Characteristics}

The typical medical waste was sampled from the same batch by random sampling method. First typical medical waste sample was sterilization by high temperature steam. Secondly, the large pieces of hard objects removed from 
the sample. Finally sample was grinded for proximate analysis and then dried for ultimate and energy analysis. The ultimate analysis of typical medical waste is show in Table 1. The ultimate analysis of a waste component typically involves the determination of the percent of carbon $(\mathrm{C})$, hydrogen $(\mathrm{H})$, oxygen $(\mathrm{O})$, nitrogen $(\mathrm{N})$ and sulfur(S). Table 1 gives the average chemical composition of combustible component of medical waste. The energy content of the medical waste is determined by a laboratory bomb calorimeter. Typical energy content of medical waste is also estimated and showed in Table 1.

\subsection{Air Supply}

The air supply in the PCC is only about $40 \%$ of the stoichiometric requirement, equal to $1 / 3-1 / 4$ of the recommended air levels (140-200\%) for traditional mass burn system [9]. In the lower part of the PCC, this air is ensured to burn out the solid char. However, in the upper zone, the PCC is acting as a gasifier. Pyrolysis is the dominant mechanism in this zone for the production of volatiles from medical waste in the absence of oxygen. The produced volatiles have been identified as $\mathrm{CO}, \mathrm{CO}_{2}$, $\mathrm{H}_{2} \mathrm{O}, \mathrm{CH}_{4}$ and other light hydrocarbons.

The air supply in the SCC is $100 \%$ of the stoichiometric requirement for complete waste combustion, so the volatiles from PCC can be decomposed completely.

\subsection{Incineration Temperature}

Armored thermocouples were installed in PCC and SCC outlet as measurement equipment of temperature. The detection accuracy of the thermocouples is $1{ }^{\circ} \mathrm{C}$. Variation of temperature with time in the PCC and SCC is shown in Figure 3. The temperature of PCC is around $640^{\circ} \mathrm{C}$. However the value varied significantly with time. Because materials of medical waste range from food products to pathological waste, there is large variation in the properties of medical wastes. These variations have a dramatic impact on the performance of medical waste incinerator.

Although the combustion and pyrolysis mechanisms in PCC are complex, it is demonstrated that the pyrolysis production of volatiles and char can be regulated by temperature [10]. The decomposition of the organic matter is normally total at these high temperatures. When the pyrolysis temperature is much lower, the production of $\mathrm{CO}$ is much decreased. The low temperature may slow down the pyrolysis process and lead to delay the time of raw waste ignition. When the pyrolysis temperature is much higher, the self-combustion process became unstable. Because high temperature present in the PCC may lead to excessive burning of the pyrolysate. It will decrease the quantity of combustive pyrolysate in the SCC. Consequently the auxiliary fuel has to be consumed to main- tain the temperature in the SCC. After several testing before operation, the optimal running temperature for the PCC was set at $660^{\circ} \mathrm{C}$. It can be found in Figure 3 that the actual operating temperature is close to the setting temperature.

The combustion temperature in the SCC is higher than $850^{\circ} \mathrm{C}$, and the temperature varied slightly with time except the heavy disturbing effect from the PCC. This indicates combustion process in SCC is more stable than the process in PCC. The novel coaxial chamber design decreases $40 \%$ outer contact area of the SCC with the environment. Heat losses are much reduced. It is easy for SCC to achieve high temperature and remain stable operation.

\subsection{Pollutants and Oxygen in the SCC}

In actual operation, whether volatiles are combusted completely in the SCC is an important performance indicator of the incinerator. Gas pollutants at different positions of the SCC were tested by portable infrared flue gas analyzer. Several verification tests of the gas analyzer were carried out before the experiment to avoid measurement errors. As illustrated in Figure 4, five sample points (labeled as 1-5) were set symmetrically along the axial direction. Point " 1 " is near the PCC exit and point " 5 " is near the SCC outlet. In the stable operation conditions, each sample point is tested for three times.

Table 1. Medical waste component.

\begin{tabular}{ccccc}
\hline \multicolumn{3}{c}{ Proximate analysis (wt.\%) } & \multirow{2}{*}{$\begin{array}{c}\mathrm{LHV} \\
(\mathrm{MJ} / \mathrm{kg})\end{array}$} \\
\cline { 1 - 3 } $\mathrm{M}_{\mathrm{ar}}$ & $\mathrm{V}_{\mathrm{d}}$ & $\mathrm{A}_{\mathrm{d}}$ & 25.63 \\
\hline 64.1 & \multicolumn{5}{c}{23.4} & $\mathrm{~S}$ & $\mathrm{O}$ \\
\hline \multicolumn{5}{c}{ Ultimate analysis (wt.\%) } \\
\hline $\mathrm{C}$ & $\mathrm{H}$ & $\mathrm{N}$ & $\mathrm{S}$ & 18.54 \\
\hline 47.54 & 7.99 & 2.02 & 0.5 &
\end{tabular}

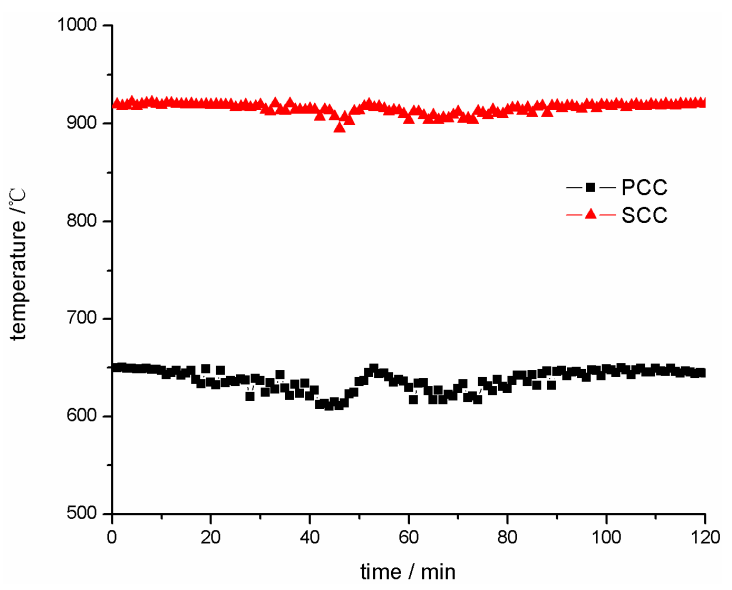

Figure 3. Variation of temperature in the PCC and the SCC. 
Concentration profiles of pollutants $\left(\mathrm{CO}, \mathrm{CO}_{2}, \mathrm{NO}_{\mathrm{X}}\right.$, and $\mathrm{SO}_{2}$ ) and oxygen are shown in Figure 5 to Figure 9. It can be seen from Figure 5 that the $\mathrm{CO}$ concentration decreases intensely from sample point " 1 " to " 5 ". This indicates that $\mathrm{CO}$ formed in the PCC is mostly destroyed in the SCC. The destruction efficiency of $\mathrm{CO}$ is round 99.95\%. It can be found from Figure 5 that $\mathrm{CO}_{2}$ is mainly formed in the SCC. The comparison between Figure 5 and Figure 6 can further explain that $\mathrm{CO}$

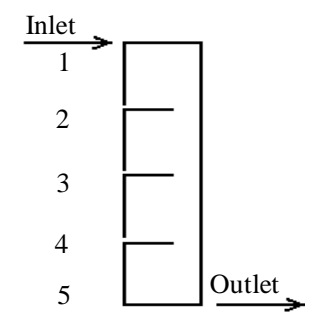

Figure 4. Sampling points distribution in the SCC.

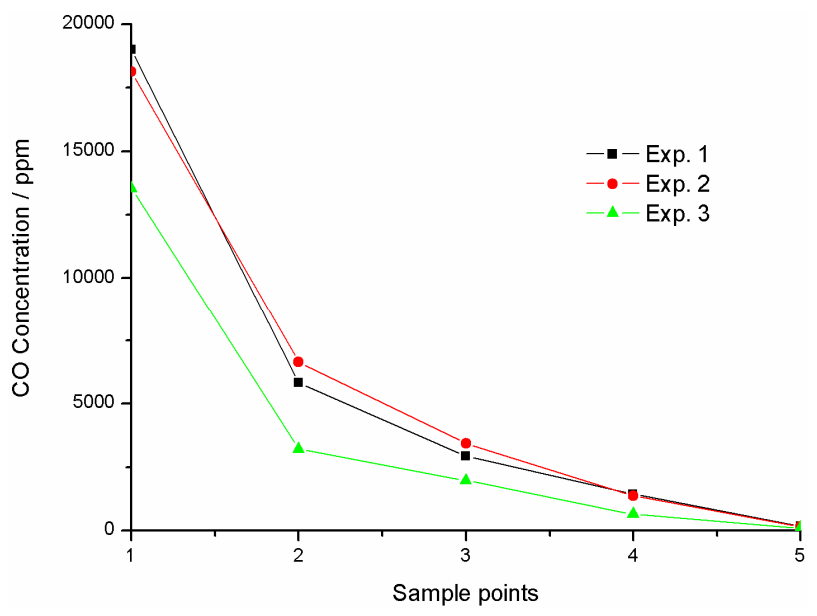

Figure 5. CO concentration.

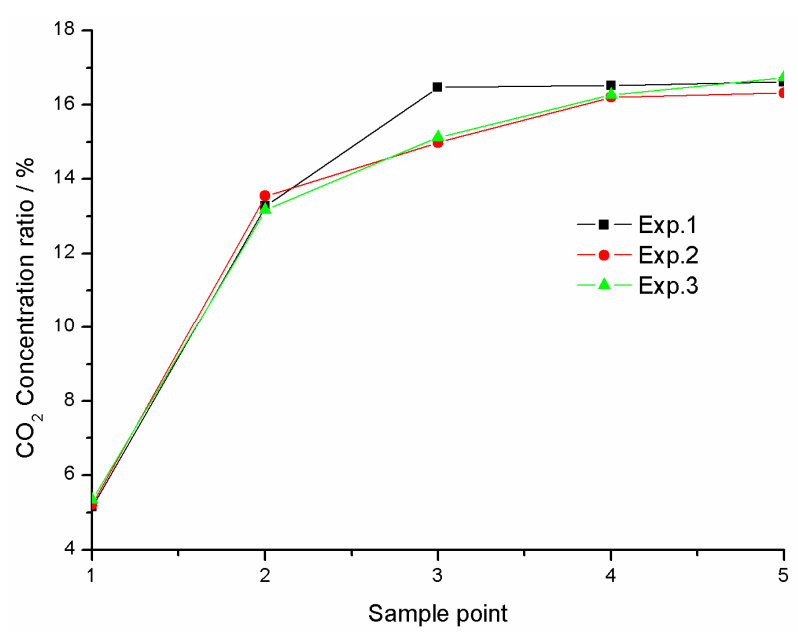

Figure 6. $\mathrm{CO}_{2}$ concentration. mostly translated into $\mathrm{CO}_{2}$ in the SCC. As is illustrated in Figure 7, concentration of oxygen is gradually decreased with the oxidation reaction going-on. Generally speaking, the concentration of oxygen in the SCC outlet is higher than $10 \%$, which meets the demand of Medical Waste Incineration Standard [11]. From Figure 8 and Figure 9, we can find that concentration of $\mathrm{NO}_{\mathrm{X}}$ and $\mathrm{SO}_{2}$ are lower than $30 \mathrm{ppm}$ and $10 \mathrm{ppm}$, respectively. These may be due to medical waste containing little $\mathrm{N}$ and $\mathrm{S}$ elements. However $\mathrm{NO}_{\mathrm{X}}$ and $\mathrm{SO}_{2}$ mainly formed in the pyrolysis process decrease little in the SCC. Conclusions can be made that combustion in the SCC has no effect on production of $\mathrm{NO}_{\mathrm{X}}$ and $\mathrm{SO}_{2}$.

\subsection{Pollutant Concentrations in the Stack}

Concentrations of $\mathrm{NO}_{\mathrm{X}}, \mathrm{SO}_{\mathrm{X}}, \mathrm{HCl}$ and particles in the

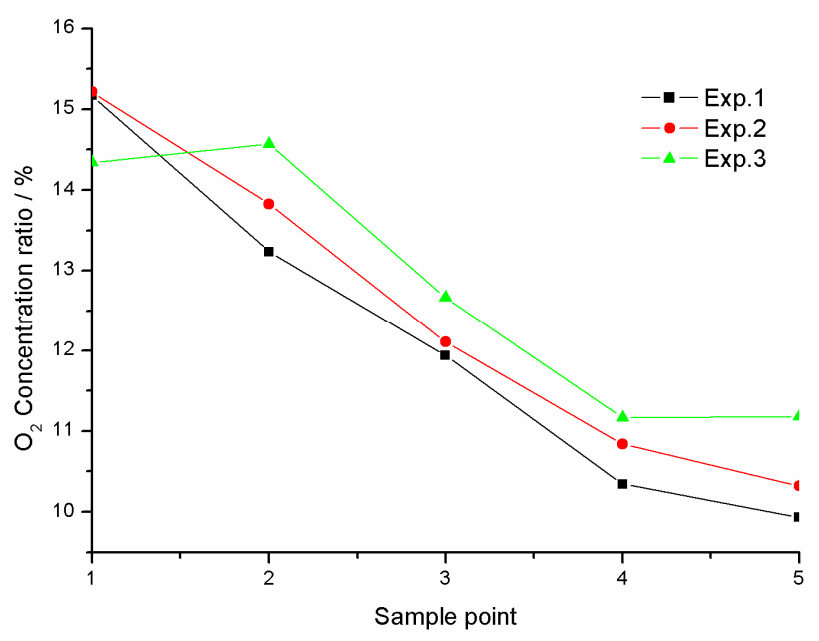

Figure 7. $\mathrm{O}_{2}$ concentration.

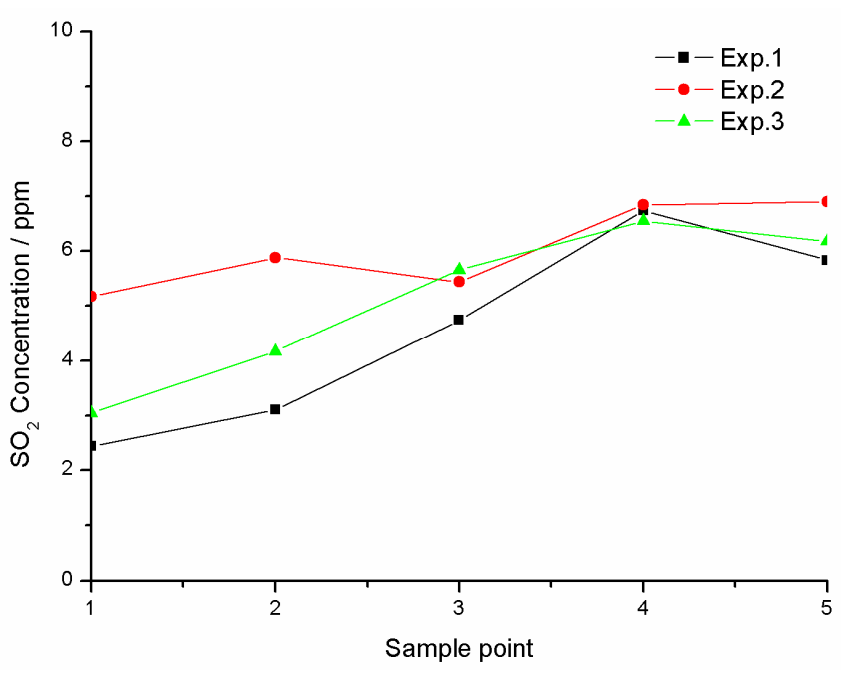

Figure 8. $\mathrm{SO}_{2}$ concentration. 


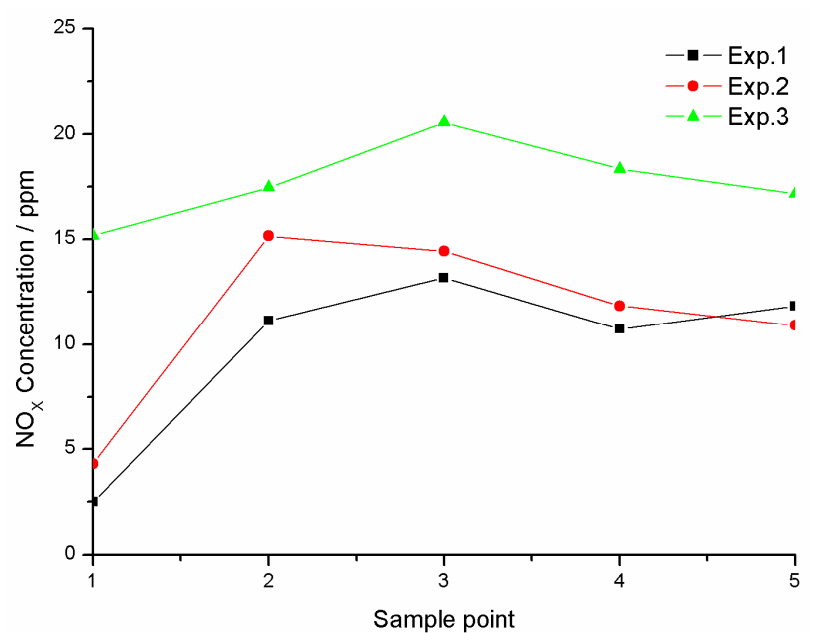

Figure 9. $\mathrm{NO}_{\mathrm{X}}$ concentration.

exhaust were measured respectively according to the $\mathrm{Ch}$ ina National Standards [11]. Concentration of $\mathrm{CO}, \mathrm{CO}_{2}$, $\mathrm{O}_{2}$ were also measured by a Combustion Efficiency Measurement Instrument.

The maximum air pollutant concentrations in the inlet of the stack are summarized in Table 2. National Incineration Emission Standard for each component is also listed in the Table 2. As shown in Table 2, the measured pollutants belong generally to the concentration range set by China National Standards. As Table 2 shows, the experimental value of particulates in the stack is much lower than the limit. In addition to the well operated bagfilter, the low air level in the PCC is an important reason. Compared with the traditional mass burning system, starved-air combustion in the PCC produces less solid particles in the gas stream. Researchers have demonstrated that the dioxin formation from carbon particulates is one of the potential mechanisms for PCDD/F formation in the post combustion zone [12,13]. The reduced fly ash entrainment in flue gas is helpful to control the dioxins. The concentration of acid gases such as $\mathrm{HCl}$ and $\mathrm{SO}_{2}$ are also lower than the limit. This demonstrates that gas scrubber is in good working condition.

\section{Conclusions}

The integral medical waste incinerator combines a feeder, a rotary grate, a primary chamber and a "coaxial" secondary combustion chamber into a unique unit. The temperature of the PCC varied significantly with time because of the intermittent feed and the heterogeneous characteristics of the raw medical waste, however, due to the coaxial SCC design, the combustion temperature in the SCC varied slightly with time. The temperature has great effect during the formation of pyrolysis gas such as CO. The low air level $(40 \%)$ in the PCC well controlled the
Table 2. Emission concentration of pollutants in the flue gas.

\begin{tabular}{ccc}
\hline Pollutants & Experimental values & Standard \\
\hline $\mathrm{CO}, \mathrm{mg} / \mathrm{m}^{3}$ & 34.8 & 80 \\
$\mathrm{NO}_{\mathrm{X}}, \mathrm{mg} / \mathrm{m}^{3}$ & 15.1 & 400 \\
$\mathrm{SO}_{2}, \mathrm{mg} / \mathrm{m}^{3}$ & 24.2 & 260 \\
$\mathrm{HCl}, \mathrm{mg} / \mathrm{m}^{3}$ & 48.7 & 75 \\
$\mathrm{O}_{2}, \mathrm{mg} / \mathrm{m}^{3}$ & 16.3 & $6-11$ \\
Particulates, $\mathrm{mg} / \mathrm{m}^{3}$ & 32 & 80 \\
Blackness & 0.8 & 1 \\
\hline
\end{tabular}

chamber's temperature. The actual operating temperature in the PCC $\left(640^{\circ} \mathrm{C}\right)$ is close to the setting temperature $\left(660^{\circ} \mathrm{C}\right)$. Consequently, char combustion is also kept stable and complete. Concentrations of pollutants in the SCC were measured on different sample points. In these data, CO level represented the best available estimate of environmentally satisfactory operation for the incineration process. The destruction efficiency of total $\mathrm{CO}$ in the SCC is round $99.95 \%$. Emission concentrations of pollutants in the stack were also measured and met the demand of the China National Incineration Emission Standard.

\section{References}

[1] R. Xie, W. J. Li, J. Li, et al., "Emissions Investigation for A Novel Medical Waste Incinerator," Journal of Hazardous Materials, Vol. 166, No. 1, 2009, pp. 365-371.

[2] J. M. Zhu, H. M. Zhu, X. G. Jiang, et al., "Analysis of Volatile Species Kinetics during Typical Medical Waste Pyrolysis Using A Distributed Activation Energy Model," Journal of Hazardous Materials, Vol. 162, No. 2-3, 2009, pp. 646-651.

[3] State Environmental Protection Administration of China, "Standard for Pollution Control on the Security Landfill for Hazardous Wastes," National Technical Standard of China (GB 18598-2001).

[4] W. R. Niessen, "Combustion and Incineration Processes," 3rd Edition, Marcel Dekker Inc, New York, 2002.

[5] C. C. Lee and G. L. Huffman, "Medical Waste Management Incineration," Journal of Hazardous Materials, Vol. 48, No. 1-3, 1996, pp. 1-30.

[6] A. F. Shaaban, "Process Engineering Design of Pathological Waste Incinerator with an Integrated Combustion Gases Treatment Unit," Journal of Hazardous Materials, Vol. 145, No. 1-2, 2007, pp. 195-202.

[7] D. E. Rogers and A. C. Brent, "Small-Scale Medical Waste Incinerators Experiences and Trials in South Africa," Waste Management, Vol. 26, No. 11, 2006, pp. 1229-1236.

[8] G. R. Woodle and J. M. Munro, "Particle Motion and Mixing in A Rotary Kiln," Power Technology, Vol. 76, 
No. 3, 1993, pp. 187-190.

[9] A. R. Lawrence, "Energy from Municipal Solid Waste: A Comparison with Coal Combustion Technology," Progress in Energy and Combustion Science, Vol. 24, No. 6, 1998, pp. 545-564.

[10] H. M. Zhu, J. H. Yan and X. G. Jiang, "Study on Pyrolysis of Typical Medical Waste Materials by Using TGFTIR Analysis," Journal of Hazardous Materials, Vol. 153, No. 1-2, 2008, pp. 670-676.

[11] State Council of China, "Decree of the Medical Waste
Management," Chinese Environmental Science Press, Beijing, 2003.

[12] L. Stieglitz and H. Vogg, "On Formation Conditions of $\mathrm{PCDD} / \mathrm{F}$ in Flyash from Municipal Waste Incinerators," Chemosphere, Vol. 16, No. 8-9, 1987, pp. 1917-1922.

[13] B. K. Gullet, K. R. Bruce, L. O. Beach, et al., "Mechanistic Steps in the Production of PCCD and PCDF during Waste Combustion," Chemosphere, Vol. 25, No. 7-10, 1992, pp. 1387-1392. 